\title{
Psychological sequelae of political imprisonment, specifically post-traumatic stress disorder, in 491 Days by Winnie Madikizela-Mandela
}

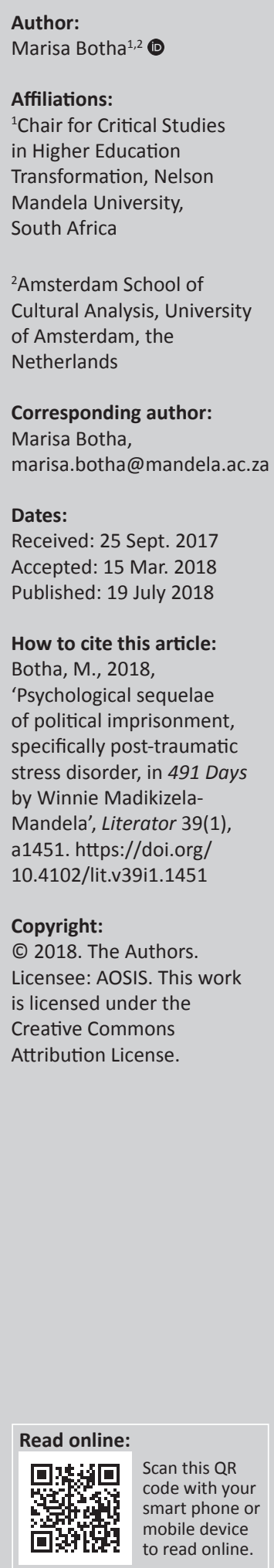

\begin{abstract}
This article analyses well-known anti-apartheid activist Winnie Madikizela-Mandela's prison memoir 491 Days: Prisoner Number 1323/69 (2013) for depictions of suffering. This memoir reveals aspects of politically inflicted trauma, particularly the suffering sustained in prolonged solitary confinement and the resulting psychological sequelae for the prisoner. To move beyond a vague understanding of her traumatic experiences, this article draws on the field of psychiatry, specifically the diagnostic criteria for post-traumatic stress disorder (PTSD) to gain greater insight as this tool may also be regarded as a type of narrative that could aid in the comprehension of traumatic events. References will be made to the three main cluster symptoms of PTSD: involuntary re-experiencing of the traumatic event, avoidance of reminders and an ongoing sense of threat. An interdisciplinary literary-psychological approach will probably lead to a deeper understanding of the mental consequences of political imprisonment, as PTSD was not an acknowledged disorder during Madikizela-Mandela's detainment.
\end{abstract}

'They destroyed your being; you are made to feel a nobody.' Winnie Madikizela-Mandela (2013:62)

\section{Introduction}

This article continues the discussion on psychological sequelae of political prisoners during a pre-democratic South Africa. Lionel J. Nicholas (2014) has also published on the psychological sequelae of political imprisonment during apartheid, but he focused on the Mandela and Sobukwe families, specifically the men, with only a few references to Madikizela-Mandela's 491 Days (2013). His article 'explores the psychological injuries sustained during apartheid and the role of psychology in its amelioration and exacerbation' (2014:1). In contrast to Nicholas' article on a few psychological aspects of political imprisonment, the purpose of this article is an exploration of one woman's torment as political detainee. ${ }^{1,2}$

Winnie Madikizela-Mandela shares her personal trauma in her memoir, 491 Days (2013), but her story is also illustrative of the fate of other political prisoners and by extension may be read as representative of South African history. By analysing representations of mental suffering in her memoir and making comprehensive correlations between her experiences and symptoms of post-traumatic stress disorder (PTSD), it becomes clear that the aftermath of political imprisonment and other heinous human rights violations committed under apartheid rule has left a mental mark on the South African society. A wider understanding of the PTSD symptoms and their manifestations prevalent in South African communities, such as anger, violent tendencies,

This article will only discuss symptoms of PTSD as they appear in this life narrative for it is not possible nor advisable, to attempt clinical diagnosis of a psychiatric disorder from a text. The references to PTSD symptoms are meant to be indicative of possible traumatic distress experienced by the political prisoner, Madikizela-Mandela, and subsequently recorded by her on paper. The exploration of this topic should not be read as definitive inferences of her mental state, past or present.

2.It is beyond the scope of this article to discuss the genderedness of female incarceration, but there are differences in the prison experiences of men and women, as well as the psychological impact of their imprisonment on their psyche. In prison, women may feel more isolated when removed from their children (Mignon \& Ransford 2012), they also have different health and hygiene concerns (e.g. menstrual cycle), they require different correctional management than male prisoners (Schram, Koons-Witt \& Morash 2004) and the most devastating gender difference is the high rate of suicide among women prisoners. In England and Wales, incarcerated women prisoners have alarmingly high rates of suicide, which is much higher than male prisoners or even women in the general population (Thomas 2009). Another study on prisoners in the USA suggests that suicide rates in prison were 'similar for female and male inmates, but rates were higher for female inmates and lower for male inmates compared to the respective rates for female and male U.S residents' (Dye 2011:290). The prisons that reported suicides among the women prisoners demonstrated 'significant differences in residents' (Dye 2011:290). The prisons that reported suicides among the women prisoners demonstrated 'significant differences in prison conditions, inluding higher assault rates and mental health service utilization, compared to prisons without suicide (Dye 2011:290). The prevalence of PTSD may vary across development and cultural groups, but the highest rates of PTSD are 'found among survivors of rape, military combat and captivity, and ethnically or politically motivated internment and genocide' (DSM-V 2013:276 author's own emphasis]). It has also been found that the female gender is potentially a pretraumatic risk factor for PTSD (p. 277). Gender-related diagnostic issues show that women are more likely to experience PTSD than men and that they usually experience PTSD for a longer duration than men (p. 278). Tautology in this formulation of women's increased risk for PTSD appears to be 'attributable to a greater likelihood of exposure to traumatic events, such as rape, and other forms of interpersonal violence', but studies also show that in 'populations exposed specifically to such stressors, gender differences in risk for PTSD are attenuated or nonsignificant' (p. 278). It is thus clear that the experience of trauma is individual, and that environment plays a greater role than gender. 
hypervigilance and anxiety, may contribute to a greater understanding of the dynamics within our society. The value of this cross-disciplinary approach, whereby literary, specifically autobiographical, and psychological tools and theoretical frameworks are utilised, may be seen in the revisionary reading and comprehension of MadikizelaMandela's autobiographical narrative, which as a South African icon is interweaved with this country's political past.

Winnie Madikizela-Mandela (1936-2018), arguably the most prominent woman liberation fighter of the 20th century in South African history, was arrested by the South African Security Police, a specialised unit dedicated to national security, in 1969. This arrest, one of many, was politically motivated as Madikizela-Mandela was an influential affiliate of the African National Congress (ANC) and the South African Communist Party (SACP). Her husband at the time, Nelson Mandela, leader of the ANC and of its military wing, Umkhonto we Sizwe, as well as a key member of the SACP, was incarcerated on Robben Island during her arrest.

Madikizela-Mandela was a complex person who fascinated and appalled the public. Her conduct has elicited strong reactions, deemed by some as heinous and others as heroic. ${ }^{3}$ The enigma Winnie Madikizela-Mandela, has been explored in books, articles and films. The latest attempt to tell her intriguing life story is the recently released documentary Winnie (2017) in which the viewer is given access to lesser known details of her life. The film does not offer excuses for her involvement in controversial acts, but it does provide much needed context for her decisions. Similarly, her memoir 491 Days (2013) provides the reader with insight into her life and the psyche of a political prisoner. The most astounding facet of this prison memoir is that Madikizela-Mandela wrote its afterword over four decades after her incarceration. This offers the reader a rare opportunity to read the author's reflections on her imprisonment and gauge her lasting reactions.

As a survivor of imprisonment, her testimony will not be interrogated for narrative truth (see Smith \& Watson 2012; Young 2013). ${ }^{4}$ The experience of trauma is personal and

3.Winnie Madikizela-Mandela, a social worker and the first qualified black woman to be appointed in this capacity at the Baragwanath Hospital in Johannesburg, is regarded by many as 'mother of the nation'. This sobriquet dates back to the 1970 s when she became a caring mother-figure to the many young people in the struggle, especially after the tragedy of the 1976 Soweto uprising when numerous school children were shot by police. Mama Winnie continued to support the youth in this pivotal role during her brief time as First Lady by her presidential husband's side the 'father of the during her brief time as First Lady by her presidential husband's side, the father of the nation', up until she passed away at the age of 81 on 2 April 2018. Munro (2014:92) points out that the 'fantasy of the nation as a family has often been used to mak crucial at that vulnerable and volatile stage in South Africa's democratic nation building. MadikizelaMandela is also regarded as 'mother of the struggle' for the important activism and political work she did during the apartheid years whilst her husband, Nelson Mandela, was imprisoned. Her laudable and deplorable acts are too many to enumerate, but suffice to mention that she supported the disadvantaged and downtrodden as one of the founders of the Black Women's Federation and the Black Parents' Association after the Soweto uprising. Her revolutionary acts later take a turn for the violent with her endorsement of the 'necklacing' torture method to punish suspected informers in the 1980s. During the same time, she forms the infamous Mandela United Football Club (MUFC), which was implicated in many cases of intimidation, kidnapping, torture and murder (see Munro 2014:101-103). In 2003, she was also convicted of fraud and theft along with her broker, but the 'four-year sentence was commuted on appeal to a suspended sentence' (Sheldon 2016:172).

4.Madikizela-Mandela's autobiography, Part of My Soul Went with Him (1985) has a chapter on this detention of 491 days but has not been included in this article for the following two reasons. Firstly, the aim is to analyse Madikizela-Mandela's memoir which was written during her imprisonment. Her earlier autobiography was published more than 15 years after this traumatic event. Secondly, there are discrepancies accordingly the British Pain Society defines pain as follows: 'Pain is what the person feeling it says it is' (Norridge 2011:209). This carte blanche definition emphasises the reactional, subjective nature of suffering. It does not focus on the traumatic event, but rather illustrates the response to the said incident, which complements Kai Erikson's opinion (1995): 'it is how people react to them rather than what they are that give events whatever traumatic quality they can be said to have'. He asserts that the most violent acts:

... have no clinical standing unless they harm the workings of a mind or body, so it is the damage done that defines and gives shape to the initial event, the damage done that gives it its name. (pp. 184-185)

What then, if any, was the damage done to Winnie MadikizelaMandela during her political detainment?

\section{Post-traumatic stress disorder}

In 1980, after decades of discussions on trauma disorders following the Vietnam War, the World Wars and the Holocaust, the American Psychiatric Association (APA) officially acknowledged PTSD in the third edition of its nosological encyclopaedia, Diagnostic and Statistical Manual of Mental Disorders (DSM-III). In 2017, 37 years later, this disorder still sparks debate in the field of psychiatry. The fact that the understanding of this comprehensive stress disorder is still evolving is a clear indication of the complexities involved with trauma diagnoses. ${ }^{5}$

Stein et al. (2016:107) explained that the pioneering idea behind PTSD, as it was incorporated into the DSM-III, was that 'seemingly disparate phenomena may be aggregated under one diagnosis within the broader class of Anxiety Disorders'. This meant that the diagnosis of what was previously known as 'Situational Reaction' in the late 1960s and traumas related to their 'etiological origins', causation of the disorders, for example, rape trauma syndrome, child abuse syndrome, battered women's syndrome, post-Vietnam syndrome, prisoner-of-war syndrome and concentration camp syndrome was classified as PTSD (Stein et al. 2016:107).

From its inception, PTSD was intended as a broad category for anxiety disorders, but over time the definition of PTSD

\footnotetext{
between 491 Days and Part of My Soul Went with Him, which could be because of the processing of traumatic memory or a deliberate representation of the autobiographical processingoftraumatic self. It should be noted that 491 Days, in its published form, is a polished autobiographical work with diary entries, judicial documents, letters and a sporadic editorial influence. It is a complex task to identify varying degrees of narrative truth in memoirs, especially where it concerns traumatic memory as this type of memory may be fragmented or diminished. Madikizela-Mandela's memoir has daily diary entries for most of her imprisonment, which may be considered more reliable as she does not have to rely on her working memory to retrieve the information as she does when she recalls the first part of her incarceration, which she recorded on paper a few months after it occurred. Another factor to consider is that the writing process, whereby traumatic memory is transformed into narrative memory, may be beneficial to regain control of one's mental state and not be beset by menacing involuntary memories. In order for the healing process to commence, the following changes need to occur:

[T]he restoration of the self and the reclaiming of one's sense of control of memory, of the capacity to reflect, understand, and to perceive things as they are or were, requires transformation of traumatic memory into narrative memory. (Van der Merwe \& Gobodo-Madikizela 2008:vii)

Narrative memory is accessed during the writing process when the victim, or rather survivor, becomes the author of her own story. Through the process of arranging her experiences in narrative form, deciding on a beginning, middle and end, she is her experiences in
reclaiming her life.

5.The developmental course of PTSD spans decades and as a diagnosis is everchanging in our modern society (for details, refer to Stein et al. 2016:107-109).
} 
has been narrowed. In the Oxford Medical publication, Psychiatry (2012), PTSD is defined as a 'severe psychological disturbance following a traumatic event, characterised by the involuntary re-experiencing of the event combined with symptoms of hyperarousal, dissociation, ${ }^{6}$ and avoidance' (Geddes, Price \& McKnight 2012:269). The forthcoming 11th revision of the International Classification of Diseases (ICD-11) by the World Health Organization (WHO) proposes a new theory of PTSD that is fundamentally a narrower description compared to previous definitions to improve recognisability (Hyland, Brewin \& Maercker 2017:1).

According to the online beta version ${ }^{7}$ of $I C D-11$, PTSD 'may develop following exposure to an extremely threatening or horrific event or series of events' and is characterised by (author's own emphases):

- re-experiencing the traumatic event or events in the present in the form of vivid intrusive memories, flashbacks, or nightmares, which are typically accompanied by strong and overwhelming emotions such as fear or horror and strong physical sensations, or feelings of being overwhelmed or immersed in the same intense emotions that were experienced during the traumatic event

- avoidance of thoughts and memories of the event or events, or avoidance of activities, situations, or people reminiscent of the event or events

- persistent perceptions of heightened current threat, for example, as indicated by hypervigilance or an enhanced startle reaction to stimuli such as unexpected noises.

It is apparent from the above criteria that the ICD-11 definition of PTSD focuses on three main elements concerning the survivor's response to the traumatic event(s): re-experiencing of the traumatic occurrence(s) in the present, avoidance of thoughts or reminders pertaining to the trauma and a continual awareness of danger. This proposed definition of PTSD requires that the symptoms persist for at least several weeks and cause 'significant impairment in personal, family, social, educational, occupational or other important areas of functioning'. This differs from the ICD-10 definition which did not require the symptoms to persist for weeks after the traumatic event (rather they must occur within six months) nor that they cause functional impairment.

There are not only many similarities between the WHO and the APA definitions of PTSD, but also differences, especially from the latest contribution from APA (the DSM-5 2013,

6.Dissociative symptoms will be discussed in a forthoming paper on complex post traumatic stress disorder (CPTSD) as it has been shown to be the most 'distinguishin feature of CPTSD compared with PTSD' (McDonnell, Robjant \& Katona 2013:3). Furthermore, dissociative symptoms will also form part of the CPTSD description in the ICD-11. Currently, CPTSD is not recognised in the $I C D-10$ or the DSM-5, but dissociative symptoms are included in their diagnostic criteria for PTSD.

7.The World Health Organization's 11th revision of the International Classification of Diseases (ICD-11) is due for publication in 2018. The online beta draft has several to the most notably that it is updated daily and not approved by the WHO. I refer ICD-11. The limited information avalable to nion avallable on the fortheming ICD-11. The limited information available to non-collaborators (non-registered users) is augmented in this article with the published ICD-10 (including the revised 2016 online version). updated in 2015) and the new proposed concept of the ICD-11 from WHO. For example, the main diagnostic criteria for PTSD is exposure to an extremely threatening or horrific event or series of events in ICD-11, which is quite broad in scope, whereas the DSM-5's Criterion A, exposure to actual or threatened death, serious injury, or sexual violence (as it applies to persons older than six years), is more specific. An individual must have experienced trauma in one or more of the ways outlined in this criterion before considering the other symptoms, which develop following the traumatic event $(2013: 271)^{8}$ :

- Directly experiencing the traumatic event(s).

- Witnessing, in person, the event(s) as it occurred to others.

- Learning that the traumatic event(s) occurred to a close family member or a close friend. In cases of actual or threatened death of a family member or friend, the event(s) must have been violent or accidental.

- Experiencing repeated or extreme exposure to aversive details of the traumatic event(s).

If one considers the experiences of Madikizela-Mandela, they are distinctly traumatic not only by $I C D-11$ criteria but also by the more detailed DSM-5. The above Criterion A.1 may be applicable to Madikizela-Mandela's imprisonment as she directly experienced the trauma of detainment and was also exposed to death threats daily (2013:234). As for learning about a traumatic incident regarding a family member (Criterion A.3), Madikizela-Mandela is present when her 18-year-old sister, Nonyaniso, testifies in court that she was tortured by the Security Branch and witnesses her physical deterioration (pp. 14, 246). Early in her detention, she also hears about the death of her stepson, Thembi Mandela, on her husband's birthday, 18 July 1969, when a police officer callously informs her 'he's dead' (p. 244). It is not clear if this family member died an accidental or violent death, but the cruel manner in which she was informed of this tragedy and the unknown causes of his sudden death were a tremendous shock. From the aforementioned incidents, it is clear that Madikizela-Mandela experienced multiple traumatic ordeals whilst imprisoned.

In this article, the predominate psychiatric theory used is the ICD-10 (2016) and the forthcoming ICD-11. As far as organising the data the ICD-11's streamlined concept, which focuses on three core symptom clusters, is preferred over the detailed diagnostic criteria of the DSM-5. The DSM-5 will, however, be utilised to elucidate or expand on certain elements of PTSD.

8.This is a short extract from DSM-5'S diagnostic criteria for PTSD, namely Criterion A, to illustrate the constantly evolving nature of PTSD theory, as well as some of the differences in criteria between the DSM-5 (2013) and ICD-11. For the sake of brevity and simplicity, I have not cited the explanatory information in the origina version's parentheses. There are also changes between the new DSM and its predecessor; for example, in the DSM-IV, PTSD is classified as an anxiety disorder and, in the latest DSM-V it has been re-classified as a trauma- and stressor and, in the latest DSM-V, it has been re-classified as a trauma- and stressorrelated disorder because the stressor or traumatic event is explicitly identified as a diagnostic criterion (APA 2013:270). Another significant difference from the $D S M-I V$ is that emotional reactions of fear, horror and helplessness is not part of Criterion A anymore. This illustrates a shift in the understanding of PTSD because it is now known that individuals respond differently to trauma. Clinical presentations of PTSD vary as different symptoms may predominate in individuals
(APA 2013:274). 


\section{Re-experiencing the traumatic events in the present}

One of the salient features of PTSD is the persistent reexperiencing of a past traumatic event(s) in the present. These intrusions associated with the traumatic event are experienced in one or more of the following ways: distressing memories, intrusive recurrent thoughts, nightmares and flashbacks. ${ }^{9}$ Flashbacks are considered a dissociative reaction in which the person acts or feels as if the trauma is recurring. The DSM-5 recognises that traumatic episodes may also be relived through internal or external factors that symbolise or resemble an aspect of the traumatic event, in which case the individual experiences 'intense or prolonged psychological distress at exposure' or 'marked physiological reactions' to these cues (APA 2013:275).

One of the most significant triggering events for Winnie Madikizela-Mandela is when she is unexpectedly confronted with her past in the form of her prison journal - loose handwritten pages on which she had recorded her 16 months in detention. She had given these papers to advocate David Soggot, who had represented her and her 21 co-accused, during their trial and thought that the journal, dubbed the 'Saga', had been lost.

In 2011, Greta Soggot, widow of David Soggot, returned the diary to her at her office in South Africa's parliament. This was 41 years after her traumatic prison experience of lengthy solitary confinement accompanied by severe mental and physical deterioration. In the introduction to 491 Days, the psychological impact of this delivery on the then 75-year-old Madikizela-Mandela is described as causing 'vivid and horrific memories' to rush back of the 'traumatic time when, as a young wife and mother of two small children, she was left alone when her husband Nelson Mandela was jailed for life for sabotage' (2013:1).

The strong bond between mother and child(ren) is foregrounded by the editors in the introduction, and rightly so as this separation certainly caused Madikizela-Mandela immense anxiety. In a cyclical manner, she emphasises this parental bond, which is intrinsically linked to the fateful night of her arrest. In the epilogue, written in November 2012, more than a year after receiving the journal, Madikizela-Mandela discloses the distressing emotions the returned diary caused:

I was fearful to go through that again, afraid of hurting myself and hurting my children because in hindsight you cannot help but think, 'what did I do to my children?' (2013:232)

She accentuates that this was the 'truth'10 and that she felt it as a 'physical experience'. The physicality, or somatic

9.In the forthcoming $I C D-11$ the criteria for PTSD only requires one of the following two symptoms for diagnosis in the re-experiencing category: distressing dreams of the trauma and/or reliving the trauma (e.g. through thoughts and memories). A third symptom, namely, if the individual does not remember the trauma clearly, may replace or be in addition to the other symptoms.

10.The notion of 'truth' is problematic as Madikizela-Mandela clearly loves her own children greatly, but this motherly concern is juxtaposed with her treatment of other children, especially the ones who were part of the MUFC. In December 1988 the MUFC kidnapped four youths, assaulted them and murdered the youngest, 14-year-old Stompie Moeketsi Seipei (Munro 2014:103). This tragic incident late response, to the diary and the accompanying vehement recollections of the event is a typical symptom of PTSD.

Her intense psychological distress is evident when she conflates her aversion to the journal with the strong negative emotion of fear (2013):

That was why I was so scared to revisit that period because seeing those pages of handwritten notes and diaries brought back that fateful day. My children, Zindzi and Zeni, were clinging to my skirt crying, 'Mummy, Mummy don't go.' It was about 2:30 or 3am and they were used to these knocks. The authorities would knock at the door, knock at the windows, kick the doors in and break the windows. But that day I knew I was going for a long period of time. So I went into prison against that background and I did not know whether the children would survive. I did not know where they were going to take them to because the police who arrested me never even asked me where they should take them. (p. 232, [author's own emphasis])

Take note of the vivid imagery of the memory: the heartbreaking scene of the young girls holding on to their mother, pleading that she should not leave them. This intrusive memory shapes the event into one where MadikizelaMandela feels guilty over leaving, when in reality she did not have a choice in that moment. ${ }^{11}$ The references to violence and racial oppression, which also affected the children ('they were used to these knocks'), allude to another more insidious form of trauma. ${ }^{12}$ After months of imprisonment, she repeatedly relives this traumatic event through terrible nightmares. She recounts that she wakes up screaming in the night:

I discovered I spoke aloud when I thought of my children and literally held conversations with them. I cried almost hysterically when I recalled their screams on the night of my arrest. (2013:23)

The toll, emotionally and bodily, of these nightmares is immense and causes her to spend the entire day walking the length of her cell with the intention of exhausting herself so that she may be able to sleep during the night (p. 23). ${ }^{13}$

Her cell was located next to the assault chamber. She relates hearing the excruciating sounds of torture through the window and walls. In her diary, after being in that cell for

became 'symbolic of her transformation, for many, into malevolent mother of the nation' (Munro 2014:104). It should, however, be noted that after her recent passing new information has come to light regarding Seipei's murder. Curiously, shortly after her death, the former Police Commissioner, George Fivaz, stated in an was found to implicate Madikizela-Mandela (eNCA, 2018).

11.Because of practical constraints, this article will not explore themes of motherhood or the perceived consequences for the children of political activists. These topics will be examined in a forthcoming article.

12.It is beyond the scope of this article to discuss the oppression-trauma relationship. There is a proven link between PTSD and racial discrimination, not only in cases of hate crimes but also in the cumulative exposure to microaggressions based on 'race' (negative stereotypes) and ethnicity (Williams 2015). The DSM-5 acknowledges the predisposition of racial minorities, like African Americans, to PTSD. In South Africa, the black population is not an ethnoracial minority, but the apartheid regime has left a legacy of trauma inflicted by racism.

13.Madikizela-Mandela only started writing her journal after she and her co-accused were re-arrested. This recollection is from the first 2-week period following her re-detention, 16 February-2 March 1970, which she describes as 'the most gruesome period l've ever gone through' (2013:23). She, however, also relates the gruesome period l've ever gone through' (2013:23). She, however, also relates the
re-experiencing of that fateful night in detail in her epilogue written in 2012, which illustrates the continual psychological impact of her arrest on her psyche. 
over a year, she shares the haunting re-experiences of that ongoing trauma (2013):

As long as I live I shall never forget the nightmares I have suffered as a result of the daily prisoners' piercing screams as the brutal corporal punishment is inflicted on them. (p. 10)

The severe impact of living in close proximity to these traumatic episodes is illustrated by her response to them. She internalises the brutality as she empathetically feels the lashes of the cane, or hose pipe, 'tearing at [her] own flesh mercilessly' when her fellow prisoners are castigated, as well as being within earshot as the matron bangs the heads of prisoners against her cell wall in 'fury' (p. 10). Besides the nightmares, she demonstrates an involuntary emotional response by crying 'time without number quite unconsciously and often forget even to wipe them [tears] off' and revealing that those 'hysterical screams pierce through my heart and injure my dignity so much' (p. 10). It is clear from the repeated nightmares and numerous emotive reactions that she was indeed re-experiencing the traumatic incidents of torture in the present moment of writing her diary at that time. It is not certain if she re-experienced these events through intrusive memories or upsetting dreams after her release from prison, but if one considers the cumulative effect of auditory witnessing of daily horrors being executed not only within earshot, but with only a wall separating her from the beatings, then it is unlikely that she speedily recovered from this ordeal, especially as she declares that she will never forget.

\section{Avoidance of stimuli reminiscent of the trauma}

The avoidance of reminders of the stressful event is another pertinent symptom of a stressor-related disorder like PTSD. The individual may avoid or attempt to avoid internal and/ or external prompts pertaining to the trauma: upsetting memories, thoughts, or feelings and/or situations, activities, people, places, conversations or objects that could arouse recollections of the traumatic event.

An individual's attempt to avoid stimuli associated with the trauma is a coping strategy to protect himself or herself from further psychological damage. It is not, however, an adaptive coping mechanism if it continues for too long and hinders the individual from actively seeking treatment or working through the traumatic experience(s). Maladaptive coping responses also include 'flight' (fleeing the scene of a crime), persistent anger (particularly if they believe that they are blameless victims of others' misbehaviour), the release of emotion through melodramatic or aggressive behaviour, excessive use of alcohol or drugs, and deliberate self-harm, which could lead to suicide (Geddes et al. 2012:266, 269). ${ }^{14}$

In prison, detainees are afforded little, if any, personal freedom. Their schedules are regulated for them by the prison staff - that is, when they must wake up, when they should go to sleep and when they may breathe fresh air. 14.These responses will be discussed in the section 'Ongoing sense of threat'.
Madikizela-Mandela succinctly describes this uneven power dynamic: 'we were completely at their mercy' (2013:234).

In these difficult circumstances, captives (traumatised individuals) usually cannot avoid reminders of traumatic experiences. Madikizela-Mandela is held for information gathering extraction purposes. As such her treatment is structured toward mental and physical exploitation that could lead to statements and confessions during interrogations. An example of this is the appropriation of her voice by imposed solitary confinement where the few words that she speaks in isolation are aloud to herself. The intention is, of course, that this would make the prisoner more inclined to speak during interrogation sessions. As Gready (2003) points out:

... the incarcerated body becomes devoid of taken-for-granted certainties, like the voice, something of which the detainee is constantly and acutely aware but over which s/ he has little or no control. (p. 81)

Winnie Madikizela-Mandela is interrogated continuously on several occasions: once for two days and two nights (2013:45), another time it was an ongoing process of three days and nights (p. 48) and in yet another instance she was kept awake for interrogation for a torturous seven days (p. 62). It stands to reason that she would have wanted to avoid the repeated trauma of interrogations, but as a prisoner this was not an option.

One of the most significant instances where MadikizelaMandela avoids stimuli that arouse recollections of her traumatic imprisonment is when she initially refused to read her prison journal when it is returned to her. In November 2012, more than four decades after her release from prison, she reveals her response to the return of this momentous textual object in its original loose pages (2013):

When the pages that make up this journal were returned to me after so many years I did not want to read them. I was afraid. There are memories you keep in a part of your brain; it is part of those things that hurt so much you do not want to remember. Getting it back after more than 40 years probed that particular part of the brain that had stored it. (p. 232, [author's own emphasis])

It is clear from this recollection that at the time she wished to avoid this traumatic reminder of her past because it was too painful to relive those memories. Madikizela-Mandela also relates stories about the lack of hygiene with the use of sanitary buckets, which were not disinfected and sometimes not even rinsed. To make matters worse, these buckets were placed next to their open plate of food. She relates a particularly disgusting episode where her plate was placed on the lid of the sanitary bucket and as a result she was repelled to such a degree that she stopped eating. She recalls that she did not eat for a month, because of the unhygienic way in which their meals were served, as well as the general appalling state of the food. She did, however, have one meal during a particularly gruelling interrogation: 
The only time I had a meal was a bacon and egg toasted sandwich when I was under interrogation for seven days and seven nights. To this day I cannot stand that - bacon and egg. (2013:62).

The avoidance of this particular sandwich, which likely reminds her of her interrogators and the punishingly lengthy interrogations where she was forced to remain awake for days on end, is significant in assessing the long-term psychological sequelae of her treatment in prison.

\section{Ongoing sense of threat}

The third cluster symptom of PTSD is an ongoing sense of threat, as evidenced by a state of autonomic hyperarousal. The increased arousal symptoms mentioned in the ICD-10 (2016) are:

- hypervigilance

- an exaggerated startle response ${ }^{15}$

- insomnia.

In addition to the above three hyperarousal symptoms, the DSM-5 lists the following indicators in its Criterion E on 'marked alterations in arousal and reactivity' (APA 2013:272, 275):

- impaired concentration

- irritability and angry outbursts (with no provocation that are 'typically expressed as verbal or physical aggression toward people or objects' $)^{16}$

- reckless and self-destructive behaviour. ${ }^{17}$

It is not required that an individual display all of the above symptoms of an ongoing sense of threat for a diagnosis of PTSD. ICD-11 requires one of the first two symptoms listed and for DSM-5 it is evidenced by two (or more) of these six symptoms. Accordingly, the symptoms will be discussed as they pertain to Madikizela-Mandela's experiences.

Finally, states of increased arousal could also include severe anxiety, panic attacks, depression, despair, restlessness and purposeless activity (Geddes et al. 2012:266).

\section{Hypervigilance}

The DSM-5 stresses, in concurrence with ICD-11's core symptom of an ongoing sense of threat, that 'heightened sensitivity to potential threats' is a frequent characteristic of PTSD (2013:275). Interestingly, this hypervigilance on behalf of the individual is not only limited to aspects related to the traumatic event, but also to incidents unrelated to the traumatic experience (pp. 275-276). One such example is of a motor vehicle accident, where the individual is particularly

15. Hypervigilance and an exaggerated startle response are the only two symptoms (as part of the core symptom of an ongoing sense of threat) proposed for the forthcoming streamlined definition of PTSD in ICD-11.

16.This symptom is problematic to analyse because as prisoners it would be difficult to determine unprovoked anger or irritability, as the very nature of being held against your will is a provocation.

17.In DSM-IV's Criterion D on persistent symptoms of increased arousal, manifestations 1-5 are listed. The DSM-5's Criterion E2 ('reckless or self-destructive behavior') is an expansion of the PTSD clinical features in DSM-IV (2000). sensitive to the potential threat of other vehicles after the accident, which is easily understood as it is directly linked to the traumatic event. However, the individual could also fear suffering a heart attack, which is not related to the traumatic experience (pp. 275-276). Similarly, in the prison experience of Madikizela-Mandela there are instances of hypervigilance, which may or may not appear to be connected to the traumatic incident.

Madikizela-Mandela senses a potential threat to her health when she becomes convinced that she is becoming a drug addict. At that time, she was taking eight different medications three times a day (2013:22); therefore, it is possible that her concerns are valid or that her fears are being fuelled by her suspicions about the police and their tactics.

It is difficult to determine when her hypervigilance is because of mental stress and when it is based on her subterfuge, as she smuggles notes out of prison and even has an informant relaying information to her (2013:55). For her, hypervigilance is a way of life even before her detainment because her activist agenda was considered treasonous. In a state of hypervigilance, one is continually aware of danger, perceived or real. This ongoing state of anxiety, being watchful and mindful of one's environment, often leads to having an exaggerated startle response and insomnia.

\section{An exaggerated startle response}

Persons with PTSD may be 'very reactive to unexpected stimuli', which causes them to be jumpy and easily startled by loud noises or sudden movements (APA 2013:276). The most prominent instance where Madikizela-Mandela presents with a heightened startle response is when doors are unlocked. The heavy steel doors cannot be opened quietly, and it is clear from her reaction that she is overly sensitive to the noise.

The seemingly auditory assault of steel doors and keys twisting in locks has an impact on Madikizela-Mandela. More than 40 years after her release, she still vividly remembers the scenario, sound and emotional response (2013):

When we arrived at Pretoria Central prison, we were all held in a certain section of the prison. Then I was removed and placed on death row, in that cell with three doors - the grille door, then the actual prison door and then another grille door. The sound of that key when they opened the first door [...] was done in such a way that your heart missed a beat and it was such a shock. You had been all by yourself with dead silence for hours and hours and hours and suddenly there would be this K-AT-LA, K-A-T-L-A. That alone drove you beserk (sic); that alone was meant to emphasise the fact that 'we are in control, not only of your being, but your soul as well and we can destroy it'. (p. 233, [author's own emphasis])

It is noteworthy that she emphasises the three doors, which underscores her isolation, as well as the noise from not one, but three cell doors. The first lock is likely the worst shock because it breaks the silence, but it stands to reason that the 
opening of the other doors also aggravated her nerves. Lastly, there is the severe reaction to the perceived malicious conduct of the wardresses, which she concedes could drive one berserk. She also highlights the uneven power dynamic, which causes great distress as they are evidently in control of her existence.

\section{Insomnia}

Sleep disturbances are typical and may be linked to 'nightmares and safety concerns or with generalized elevated arousal that interferes with adequate sleep' (APA 2013:276). In solitary confinement, sleep deprivation is common because the dim light bulb is never switched off (Madikizela-Mandela 2013:24). The continuous light wreaks havoc with prisoners' circadian rhythms as their bodies are deprived from the natural progression from day to night, from light to dark. Thus, prisoners must contend with this additional hindrance to their sleep pattern.

Madikizela-Mandela suffers from restless sleep because of her environment of constant artificial light, but mostly attributed to psychological strain. She experiences fitful sleep caused by her environment, which is likely worsened by days of sleep deprivation during interrogations, which disrupts her sleep pattern $(2013: 45,54)$. Furthermore, she develops a 'new type of attack at night' after she is punished for screaming at a security policeman and subsequently deprived of three meals the following day (pp. 19-21). The severe stress of the quarrel and punishment manifests physically as a combination of fainting, numbness, difficulty breathing and uncontrollable aching spasms:

It would start off as a blackout although I would be lying flat and slightly propped up. I then felt completely numb, the whole body - I lose complete control over my muscles and struggle to breathe and [have an] irregular heart beat (sic). The body then jerks into functioning in a very painful spasm. I then breathe very fast and sweat a lot. (p. 21)

These frightening attacks where she loses control over her body and displays classic symptoms of hyperarousal with an elevated heart rate and excessive sweating lead to a fear of sleeping. The somniphobia causes her tremendous anxiety and she purposely attempts to remain awake so as not to experience those attacks again (2013:21). After the attacks, her medical condition weakens, and she also suffers, among other ailments, from urine retention (p. 21).

The psychologically crippling effects of severe insomnia (which may be exacerbated by medication) are illustrated by her sleepwalking, night terrors, talking in her sleep and hysterical crying (2013:22-23). She requires medication to sleep (in increasing doses) and finds that she cannot sleep without it (pp. 22, 23). Her mental and physical fatigue at times drives her to exhaust herself with physical exertion to induce sleep and she even admits to begging the matrons for her sleeping pills so that there may be the possibility of sleep (p. 23).

\section{Impaired concentration}

Problems with concentration are also commonly associated with PTSD when a person cannot perform 'focused tasks', as the DSM-5 describes it (APA 2013:276). Madikizela-Mandela demonstrates difficulty concentrating when she struggles to retain information whilst reading and even after rereading a sentence several times, she still 'absorbed nothing at all' (2013:21).

In Psychiatry (2012) the hyperarousal symptoms of restlessness and purposeless activity are also grouped together with impaired concentration (Geddes et al. 2012:266). A few examples of Madikizela-Mandela displaying these two symptoms are when she paces in her cell (2013:9) or continually polishes the floor 'to keep sane' (p. 62).

\section{Reckless and self-destructive behaviour}

Individuals with PTSD may engage in irresponsible or self-destructive behaviour such as risky driving, excessive alcohol or drug use, or self-injurious or suicidal behaviour (APA 2013:276). During her detention, Madikizela-Mandela obviously did not partake in dangerous driving or substance abuse, but the vicissitudes of prison life drove her to episodes of self-injury and attempted suicide.

She experiences severe weight loss during her incarceration. This is attributed to a few factors, such as her deteriorating mental and physical health, as well as periods of severe food restriction and a lengthy hunger strike (p. 71). Her hunger strike formed part of a more intricate suicide plan by which she would gradually 'die of natural causes' in order to spare her family the truth (p. 25). By the second week of April 1970, she discontinued treatment for her severe ailments, stopped eating and sustained herself on one cup of coffee per day and she no longer even attempted to sleep (p. 26). Her attacks increased in severity, but she did not ask to see a doctor. She later decided to leave a suicide note so that her death could be her contribution to the struggle as it would attract international attention and touch those South Africans who still had a conscience (p. 26). After a few weeks, news of a future trial changed her plans (p. 28), by that time her condition had deteriorated to the point that she had to be hospitalised (p. 27).

Preceding the suicide ideation, she describes the 'tortuous mental agony of solitary confinement' from which she and her colleagues would be saved if she took her life. For her the 'long empty hours tore through the inner core' of her 'soul' and she would hit her 'head against the cell wall' as the '[p]hysical pain was more tolerable' (p. 25). This explicit episode of self-harm attests to the inhumane nature of solitary confinement, especially for the extended periods that she had to endure in isolation.

\section{Aftermath of imprisonment}

Earlier, I had posed the question: what, if any, was the damage done to Winnie Madikizela-Mandela by her captors 
and her experience of imprisonment, especially her prolonged isolation in solitary confinement? The ostensible riposte to this question, if one considers only outward appearances or publicised news, is the dubious conclusion of only minor damage.

In the foreword to 491 Days, Ahmed Kathrada (2013:x) writes: 'Because of her commitment, loyalty, courage, determination and resilience, Winnie emerged from this long spell in detention unshaken and proud, with her head held high'. Madikizela-Mandela's public persona exudes an aura of unwavering confidence. She would continue her role as 'mother of the nation', her leadership position in political activities and later become a member of parliament.

After displaying characteristic PTSD symptoms of avoidance by initially refusing to read her diary, she later not only immerses herself in the text, but writes an afterword for her book. This may seem contradictory to this classic PTSD symptom, but she appears to take these actions to leave a legacy of her life's work, of her contribution to the struggle for freedom in South Africa. In her own words, the publication of her memoir is for 'the sake of posterity, to be able to tell our children and grandchildren what we went through' (2013:232).

Madikizela-Mandela spent 16 months in prison of which more than a year was in solitary confinement. Revealingly she refuses to eat a bacon-egg sandwich, even decades after her imprisonment, because her interrogators gave her one during an interrogation. She also admits to still being haunted by the screams of her children on the night of her arrest and possibly also the unforgettable cries of her fellow inmates being tortured. This could be indicative of chronic PTSD (CPTSD) as she is still avoiding reminders of her incarceration, but without psychiatric assessments it is impossible to determine with certainty. ${ }^{18}$

\section{Conclusion}

Post-traumatic stress disorder may develop after exposure to extremely threatening or horrific events and is characterised by cluster symptoms of re-experiencing, avoidance and an ongoing sense of threat, which is evident by a hypervigilant state. In an exploration of the memoir of Madikizela-Mandela, it has been shown that at the time of writing, and in her case more than 40 years later, she exhibits signs of PTSD. There are examples of her involuntarily re-experiencing traumas through memories and nightmares, attempts at avoiding reminders, people and places that caused her extreme

18.In the $I C D-11$ and $D S M-5$, PTSD-related symptoms are known to cause functional impairment in physical, social and occupational areas. Although it may seem as if there is little impairment in Madikizela-Mandela's professional life, this is not necessarily accurate. Nor can it be determined from this memoir to what extent she experienced problems with personal relationships after her release for example. Besides, further discussion on this aspect may be moot (at least for the example. Besides, further discussion on this aspect may be moot (at least for the purposes of this article), as studies have shown that the correlation between symptom severity and functional impairment is moderate and this relationship varies across studies' (Donahue et al. 2017:13). Also, one should consider the possibility of 'delayed expression' (previously 'delayed onset' in DSM-IV) of traumatic indicators. Symptoms typically start within the first three months after trauma, but there could be a delay of months or even years before the full criteria for a PTSD diagnosis are met (APA 2013:276). distress, and finally she presents with increased arousal (hypervigilance) symptoms as she appears to be in a state of continual anxiety and fear.

Her experience of 491 days in political detainment, which led to severe psychological sequelae, is not only a part of her personal history, but also of South Africa's history. Cathy Caruth elucidates the correlation between PTSD and the past succinctly (1995):

If PTSD must be understood as a pathological symptom, then it is not so much a symptom of the unconscious, as it is a symptom of history. The traumatized, we might say, carry an impossible history within them, or they become themselves the symptom of a history that they cannot entirely possess. (p. 5)

How do you measure suffering? How do you estimate the damage done to an individual's psyche? I have utilised psychiatric tools in an attempt to give voice and shape to the pain experienced by Madikizela-Mandela in her narrative. As pain is subjective, the reader cannot claim to fully grasp the extent of the suffering experienced by the author, especially if one considers that she grappled with the enormity of her situation during the writing process and after her release from prison.

It is difficult to define suffering, to comprehend the incomprehensible. The theory of PTSD, as a tool to diagnose and subsequently treat individuals for psychological distress, may also be considered a narrative of sorts, a way of making sense of traumatic events in order to continue living. Because of practical constraints, I could not explore the debates within the field of psychiatry in more detail. The brief introductory comments on the differences in diagnostic criteria were intended to highlight the ever-evolving concept of trauma and that even among psychiatric professionals there is not one finite conclusion regarding trauma or a course of treatment. The definition of PTSD, even 37 years after its official inclusion in medical textbooks, is still being refined to improve treatment by giving the most accurate possible diagnosis. Suffering may be treatable with psychiatric assistance, but at its heart it remains a mystery, an incomprehensibility. At best, this article has aided in the understanding of the deeply traumatic experiences of Madikizela-Mandela's political imprisonment and illustrated that it is not a simple task to measure the immeasurable. Politically inflicted suffering remains part of the pernicious legacy of apartheid and it is only in a sustained pursuit of empathetic understanding that healing may be achieved.

\section{Acknowledgements}

The manuscript for this publication was prepared with the support of the African Humanities Fellowship Program established by the American Council of Learned Societies with a generous grant from the Carnegie Corporation of New York.

The financial assistance of the National Research Foundation (NRF) toward this research is also acknowledged. Opinions 
expressed and conclusions arrived at in the article are those of the author and are not necessarily to be attributed to the NRF.

The author expresses gratitude to the anonymous peer reviewers for their insightful comments and helpful suggestions.

\section{Competing interests}

The author declares that she has no financial or personal relationships which may have inappropriately influenced her in writing this article.

\section{References}

American Psychiatric Association (APA), 1980, Diagnostic and statistical manual of mental disorders, 3rd edn., American Psychiatric Association, Washington, DC.

American Psychiatric Association (APA), 2000, Diagnostic and statistical manual of mental disorders, 4th edn., text revision (DSM-IV-TR), American Psychiatric Association, Washington, DC.

American Psychiatric Association (APA), 2013, Diagnostic and statistical manual of mental disorders, 5th edn., American Psychiatric Association, Arlington, VA.

American Psychiatric Association (APA), 2016, DSM-5 Update, August 2015, Supplement to Diagnostic and statistical manual of mental disorders, 5th edn., American Psychiatric Association, Arlington, VA.

Caruth, C. (ed.), 1995, Trauma: Explorations in memory, Johns Hopkins University Press, Baltimore, MD.

Donahue, J.J., Khan, H., Huggins, J. \& Marrow, T., 2017, 'Posttraumatic stress symptom severity and functional impairment in a trauma-exposed sample: A preliminary examination into the moderating role of valued living', Journal of Contextual Behavioral Science 6(1), 13-20. https://doi.org/10.1016/j.jcbs.2017.01.003

Dye, M.H., 2011, 'The gender paradox in prison suicide rates', Women \& Criminal Justice 21(4), 290-307. https://doi.org/10.1080/08974454.2011.609400

eNCA, 2018, 'No evidence linked Winnie to Seipei murder: Former police commissioner Fivaz', viewed 05 April 2018, from http://www.msn.com/en-za/news/politics/noevidence-linked-winnie-to-seipei-murder-former-police-commissioner-fivaz/arAAvut $4 f$ ?ocid=ientp

Erikson, K., 1995, 'Notes on trauma and community', in C. Cathy (ed.), Trauma: Explorations in memory, pp. 183-198, Johns Hopkins University Press, Baltimore, MD.

Geddes, J., Price, J. \& McKnight, R., 2012, Psychiatry, 4th edn., Oxford University Press, Oxford.

Gready, P., 2003, Writing as resistance: Life stories of imprisonment, exile, and homecoming from apartheid South Africa, Lexington Books, Lanham, MD.

Hyland, P., Brewin, C.R. \& Maercker, A., 2017, 'Predictive validity of ICD-11 PTSD as measured by the impact of event scale-revised: A 15 -year prospective study of political prisoners', Journal of Traumatic Stress 30(2), 125-132. https://doi. org/10.1002/jts.22171

Madikizela-Mandela, W., 2013, 491 Days: Prisoner number 1323/69, Picador Africa, Johannesburg.

Mandela, W., 1985 (1984), Part of my soul went with him, M. Benson (adapter) A. Benjamin (ed.), W.W. Norton \& Company, New York.

McDonnell, M., Robjant, K. \& Katona, C., 2013, 'Complex posttraumatic stress disorder and survivors of human rights violations', Current Opinion in Psychiatry 26(1), 1-6. https://doi.org/10.1097/YCO.0b013e32835aea9d

Mignon, S.I. \& Ransford, P., 2012, 'Mothers in prison: Maintaining connections with children', Social Work in Public Health 27(1-2), 69-88. https://doi.org/10.1080/1 9371918.2012.630965

Munro, B., 2014. 'Nelson, Winnie and the politics of gender', in R. Barnard (ed.), The Cambridge companion to Nelson Mandela, pp. 92-112, Cambridge University Press, New York.

Nicholas, L.J., 2014, 'Psychological sequelae of political imprisonment during apartheid', South African Journal of Psychology 44(1), 18-29. https://doi. org/10.1177/0081246313516262

Norridge, Z., 2011, 'Comparing pain: Theoretical explorations of suffering and working towards the particular', in A. Behdad \& D. Thomas (eds.), A companion to comparative literature, pp. 208-224, Blackwell Publishing Ltd, Chichester, West Sussex, United Kingdom.

Schram, P.J., Koons-Witt, B.A. \& Morash, M., 2004, 'Management strategies when working with female prisoners', Women \& Criminal Justice 15(2), 25-50. https:// doi.org/10.1300/J012v15n02_02

Sheldon, K., 2016, Historical dictionary of women in sub-Saharan Africa, Rowman \& Littlefield, Lanham, MD.

Smith, S. \& Watson J., 2012, 'Witness or false witness?: Metrics of authenticity, collective I-formations, and the ethic of verification in first-person testimony', Biography 35(4), 590-626. https://doi.org/10.1353/bio.2012.0047

Stein, J.Y., Wilmot, D.V. \& Solomon, Z., 2016, 'Does one size fit all? Nosological, clinical, and scientific implications of variations in PTSD Criterion $A^{\prime}$, Journal of Anxiety Disorders 43, 106-117. https://doi.org/10.1016/j.janxdis.2016.07.001

Thomas, S.P., 2009, 'Suicides of women in prison', Issues in Mental Health Nursing 30(6), 353-353. https://doi.org/10.1080/01612840902812921

Young, S., 2013, 'Rehearsing trauma: The reader as interrogator in prison narratives', Journal of Literary Studies 29(2), 101-116. https://doi.org/10.1080/02564718.20 13.777146

Van der Merwe, C. \& Gobodo-Madikizela, P., 2008, Narrating our healing: Perspectives on working through trauma, Cambridge Scholars Publishing, Cambridge.

Williams, M., 2015, 'The link between racism and PTSD', viewed 12 June 2017, from https://www, psychologytoday,com/blog/culturally-speaking/201509/the-linkbetween-racism-and-ptsd

Winnie, 2017, Directed by Pascale Lamche.

World Health Organization (WHO), 2016, International classification of diseases (ICD-10), viewed 22 May 2017, from http://apps.who.int/classifications/icd10/ browse/2016/en

World Health Organization (WHO), 2017a, ICD-11 Beta Draft, viewed 22 May 2017 from http://apps.who.int/classifications/icd11/browse/f/en

World Health Organization (WHO), 2017b, International classification of diseases, 11th edn., manuscript in preparation. 